\title{
Red zone blues: Violence and nostalgia in Guatemala City
}

\author{
Katherine Saunders-Hastings \\ University College London
}

\begin{abstract}
Based on ethnographic research in a Guatemala City mara territory, this article examines the place of nostalgia in residents' accounts of spiralling insecurity and gang violence. Anchoring many depictions of their circumstances past and present, emotional and narrative structures of decline and nostalgia pervaded interviews, interactions, and the research experience here. While discourses of loss and longing pose certain methodological quandaries for attempts to reconstruct processes of change in a volatile environment, I propose that they do communicate true and valuable information for understanding the social experience of violence in Guatemala City's gang territories. I also argue for understanding nostalgia as a resource - for inhabitants and for ethnographers alike - in the face of 'ontological insecurity' in violent fields. Providing reassuring narratives and tools for articulating normative claims for our informants, nostalgia also holds a strong appeal for ethnographers, presenting both dilemmas and possibilities in researching and representing contemporary insecurity.
\end{abstract}

\section{Keywords}

Guatemala City, nostalgia, ethnography, ontological insecurity, violence, gangs, barrios

\section{Introduction}

'Every day there is something worse than the day before,' Ingrid said. A middle-aged teacher in Guatemala City, she shook her head over a newspaper reporting the discovery of the mutilated corpse of a seven-month old baby in some disreputable corner of the city. Twenty years on from the end of the country's civil war, many Guatemalans shared her sense that things seemed to keep sliding a little more out of control, a little further from decency, a little deeper into uncertainty. Nowhere has been more associated with this perception of decline than the city's 'red zones' where urban insecurity is seen to concentrate. $^{1}$

In Colonia el Romero, a notorious neighbourhood said by one resident to be the 'reddest zone there is,' people spoke of things becoming harder, scarier, and uglier, of a barrio no longer what it once was. ${ }^{2}$ They said there was more violence, that it was more disruptive than before. Inhabitants linked this transformation of local insecurity to changing group cultures and criminal economies of maras, the gangs that help give northern Central America - its marginal urban communities in particular - some of the world's highest

\section{Corresponding author:}

Katherine Saunders-Hastings, University College London, Institute of the Americas, Gower Street, London, WC1E 6BT, UK. Email: k.saunders-hastings@ucl.ac.uk. 
homicide rates. Explanations of how and why things worsened for this neighbourhood often turned on the demise of 'códigos de barrio' (neighbourhood codes) that had organized certain expectations within the community, within gangs, and between the community and local cliques.

These accounts of crisis, loss, and codes coming apart were compelling, but they did not enable straightforward reconstruction of this neighbourhood's history of gangs, violence, and insecurity. They could be contradictory, elliptical, vague, and fantastical. They were acts of nostalgia, a mood and narrative mode typically discussed in terms of distortion and misapprehension. Unlike Rodgers (this volume), I had not been present to observe the trajectory they described, and so struggled with how to assess these narratives and what I could learn from them about violence and change in El Romero.

But engaging nostalgia ethnographically means more than just untangling it from the data to get at the true story, the pure past. It requires carefully unpacking multiple registers on which nostalgic narratives speak about past, present, and change, asking what they reveal about how people are living with and thinking about the violence around them and its effects on their social and moral worlds.

This paper explores these problems and possibilities of nostalgia for ethnographic research and writing, drawing on a 'functionalist' approach to nostalgia that examines it as 'a force that does something' for people in the present (Dames, 2010: 272). Nostalgia, crucially, works on and for researchers as much as our informants, in and through our ethnographic accounts as much as our field sites. Ethnographers are no less liable than their interlocutors to employ nostalgic tones of regret and 'indignation in front of loss and crisis' (Berliner, 204: 30). Throughout this paper, I therefore consider how I felt, understood, and used nostalgia for the códigos de barrio alongside reflections on the significance and function of these discourses for El Romero's residents.

Following an introduction to El Romero and to narratives of its codes and their decline, I explore the relationship between insecurity and nostalgia for both informants and ethnographers. I then turn to evaluating local nostalgic discourses, distinguishing between what we can discern from them on the level of 'reality' and that of 'truth' (Fassin, 2014). Examining what they say about the relationship between gangs and their neighbourhoods, I propose that barrio codes are best understood as accounts of a changing morality of violence in Guatemala City's red zones. I argue in the final sections for understanding nostalgia as a mode of social critique that, firstly, enables barrio residents to articulate a range of normative claims and, secondly, provides a resource for ethnographers facing certain dilemmas of representation characteristic of violent fields.

\section{The barrio and its codes}

A compact concrete peninsula, El Romero spills down a steep slope jutting out into one of Guatemala City's deep ravines. It sits in one of the most violent of the capital's 22 subdivisions; during my fieldwork, its zone accounted for nearly a quarter of the city's 
homicides (Mendoza and Méndez, 2013). Following rapid growth after Colonia el Romero's late-1970s foundation, the early 1990s saw the first informal settlements (asentamientos) occupied by new urban migrants and the neighbourhood's second generation. The denselyinhabited area comprises the original planned community (colonia) as well as numerous asentamientos filling every open space. Due to the sector's extensive informal occupation and population mobility, statistics are unreliable and rapidly outdated, with population estimates ranging from 14 to 34 thousand.

Local nostalgia does not look back to a time before gangs, but to a time when gangs are seen to have been less violent, predatory, and disruptive of neighbourhood life. From El Romero's early years, its boys and young men formed 'pandillas de cuadra' (street-corner gangs). They smoked, drank, partied, sometimes stole, and often fought with rival groups. But they are frequently said to have refrained from victimizing locals. Arturo, a local educator, community organizer, and close informant, emphasized this in describing the gangs of the late 1980s, when he was a teenager. He claimed those who took part placed 'a lot of emphasis on defending the barrio. Not just from other cliques, but seeing to it that there weren't thefts, assaults, or rapes.'

The Mara Salvatrucha (MS-13) and Barrio-18 (M-18) appeared in Central America in the early 1990s, spreading quickly by hybridizing Californian gang culture with existing local forms and traditions. ${ }^{3}$ The cliques that multiplied around El Romero from 1993 were still essentially pandillas de cuadra, but now branded as MS-13 or M-18 and using imported slang, style, tattoos, and cultural references. According to Arturo, people initially 'saw it as something pretty funny and harmless. They had an attitude of protecting the barrio.' Another long-time resident recalled that throughout the 1990s 'there were maras, but maras that weren't troublesome.' By the end of that decade, though, the violent capacity and criminal propensities of local maras seemed to be increasing.

Beginning in 2002, El Romero's gangs fought each other in what residents called the 'War of the Maras', which ended in 2008 when one Barrio-18 clique eliminated their last rivals in a murderous campaign. They have controlled the neighbourhood since, operating a criminal economy centred on the extortion of households, stores, markets, services, and transportation in their territory. A network of collaborators carries out surveillance, gathers intelligence, delivers extortion demands, and collects payments. These collaborators range from small children to elderly women, and are far more numerous than the gang members themselves. ${ }^{4}$

It was as extortion expanded under the dominance of a single clique that many residents said things went 'from worse to worse every day'. People began fleeing the neighbourhood; in some sectors, one third of homes were abandoned. Many who remained became averse to visibly improving their material circumstances, lest they trigger an extortion demand. As Arturo explained, 'if you have anything of interest to them-a car, a motorcycle, you fix up your house-you're fucked. Just fucked.' Shops shut under the pressure of extortion, with the few remaining reportedly managed by gang members' families. Residents complained of a different feel to barrio life, contrasting abandoned houses and empty streets with 
memories of neighbourhood parties, bustling alleys, and open doors. 'It was all really joyful', one older woman recalled, specifying, 'I say was, because it's gone now.'

However, not everyone saw the trajectory of insecurity in the same way. There were conflicting versions of the past and present, competing memories and nostalgias. Cadejo, a theatre performer and youth advocate from the neighbourhood as well as one of my closest informants, was involved with one of El Romero's earliest Barrio-18 cliques during his adolescence and early adulthood in the 1990s. Although he used 'códigos de barrio' to reference a time before gang crime targeted neighbourhood residents, Cadejo also said that in any period you might have been robbed in El Romero. However, his friend Wuicho, raised there at the same time and with a similar biography, insisted that 'before, they didn't rob you in the Colonia.' Some residents disputed what the mara's evolution had meant for their safety. One younger man maintained danger had decreased after a single mara took control because instead of chaotic shootings between gangs, the reigning clique simply acted directly against whoever they wanted to punish. Others saw little difference for better or worse. 'It's changed,' according to an elderly woman who has lived in El Romero since its foundation, 'but not much. There have always been deaths.'

Despite such disagreements, to which I return in later sections, there was a prevailing narrative of decline in which the codes of the barrio often provided a focus for nostalgia, anchoring explanations of what went wrong for the barrio and its residents. According to this popular script, the neighbourhood's real trouble began when gangs 'started to break all those codes that existed,' governing both their internal affairs and their relations with the broader neighbourhood. ${ }^{5}$ The maras' rules about how, when, and against whom they used violence or committed crimes were principally intended for their members. But to the extent they were reliably observed, they decreased unforeseen outbreaks of violence and allowed residents to anticipate what they could expect from gangs (see Rodgers, 2006: 276-77). Residents' complaints about rising insecurity included the destabilization of that predictability. Colocho, a barrio native and schoolteacher in his thirties, told me that whereas violence used to be limited and regulated, 'now there is no control whatsoever. It is the law of the jungle.'

During my time in El Romero, I came to know a number of men who had taken part in local mara cliques at various stages in their evolution - many of them through Cadejo and his close friend and fellow former Barrio-18 member Rafa. In interviews and conversations, these ex-mara participants often invoked codes to explain how their gangs had changed, offering explanations like 'the codes are different,' 'the codes changed,' or 'those were different codes.' Murci, a Barrio-18 member in the late-1990s, claimed their codes then mandated 'protection of our barrio, protecting the space.' Asked whether he ever collected renta (extortion), a contemporary of Murci's in another local clique said, 'Nah, man. We had to take care of the barrio.' There was general acknowledgment that, in the words of another ex-member, it was 'just bad form to rob your own people, you know?'

These restrictions on legitimate violence and victims seemed to have vanished. Kevin, who joined El Romero's Barrio-18 clique in 2008, lamented how things had changed from his 
older brother's time in the mara: 'Before, the code was to take care of the barrio and not to mess with the people.' But instead protecting the neighbourhood as a gang member, he found that 'more than anything else, you destroy it.'

According to residents, the mara's abandonment of its code not only changed the relationship between gangs and the neighbourhood, but also among neighbours more broadly. The phrase código de barrio can take on different inflections and spheres of reference. Whereas ex-mara members use it to denote rules organizing and limiting violence and a protective attitude towards their home territory, for others in El Romero it evokes broader community norms. More than to describe specific rules, residents used barrio codes to refer to basic standards of decency and an ethic of trust and reciprocity. They blamed the mara's extortion, violent discipline, and web of collaborators for splintering this community ethos. They believed fear and suspicion had undermined local relationships, leading people to retreat from shared spaces and from each other, thereby damaging the social networks that enabled small favours and daily help between neighbours.

Cadejo described El Romero in the present as 'a completely fractured context' compared with the 1980s and 1990s. According to him, the código de barrio then meant 'solidarity between everyone in the barrio.' Arturo concurred that the code of the barrio in his youth meant 'hacemos huevos entre nosotros': we get by by helping each other out. Both attributed this mutualist outlook to hardships faced by El Romero's earliest inhabitants. Settling the urban frontier with extremely limited resources, they needed to cooperate, pool resources, and trade favours in order to build homes, establish local infrastructure, and maintain their households. These strategies for buffering themselves and each other from precarity were incorporated into local definitions of what it meant to be a decent person, family, and community.

People contrasted that habit of neighbourhood solidarity in the past with a ruthless selfpreservation shaping behaviour in the present. Mono, a local teenage activist a generation younger than Cadejo and Arturo, similarly defined the codes as 'all those social relations within the community, that feeling of solidarity.' But he did not see those relations or that feeling as part of his experience or that of his peers: 'Now, man, it's like "save yourself, if you can."'

\section{Insecurity and nostalgia}

To make sense of this nostalgia, we must appreciate the kinds of insecurity people face in places like El Romero. Their predicament is about much more than an elevated exposure to physical violence; they emphasized not so much a growing quantity, but a changing quality that made local violence more distressing and less manageable. ${ }^{6}$ Ethnographies of postwar Guatemala often note this shifting understanding and experience of insecurity. From the capital to the countryside, researchers have encountered individuals and communities reporting a 'constant grinding anxiety' (Nelson and McAllister, 2013: 7) and a sense of being 'betrayed by social conditions that now made them feel unsafe' (Little, 2009: 58). Distress 
about postwar insecurity in El Salvador similarly concentrated less on actual rates of violence than 'anxiety about unnerving shifts in social relations' that made violent crime seem more pervasive and less predictable (Moodie, 2009: 82).

In El Romero, people often relied on the decline of the códigos de barrio to account for shifts in the lived experience of insecurity in terms of changing norms, expectations, and values related to violence and reciprocity. As a shared normative vocabulary, the barrio codes distilled a local 'social imaginary', a common understanding of how people exist together and relate to each other (Taylor, 2002: 106). Social codes have two dimensions: the predictive-how people are likely to behave, for instance when or where violence may be expected-and the moral-how people ought to behave, under what circumstances the use of violence may be legitimate (Hart, 1994: 8-11, 55-59). When people in El Romero said that barrio codes had broken down, they expressed an uncertainty rooted in no longer knowing what to expect or fear from one another; they spoke of a disorder both practical and ethical.

What they felt can be compared to the 'cognitive and emotional disorientation' of what Giddens terms 'ontological insecurity' (1991: 37). Ontological security rests on social, emotional, and behavioural 'formulae' that sustain trust in the safety and solidity of everyday life (Giddens, 1991: 44). That sense of being firmly placed in one's world is often thrown into disarray by violence. Amid such dislocation, nostalgia emerges as a resource for people 'seeking to balance themselves' by reaching back to a past that seemed 'more human, safer, more moral' (Boyer, 2010: 118). Offering 'reassuring self-narratives' with 'anxietymitigating benefits,' nostalgia is mobilized towards meeting the 'psychic costs' of change and instability (Brown and Humphreys, 2002: 152, 155). The nostalgia I encountered in El Romero can thus be seen as both an expression of and response to ontological insecurity.

My informants, however, were not the only ones feeling insecure. In volatile and violent settings, 'horizons of doubt and change encompass ethnographers along with the people among whom they work' (Greenhouse, 2002: 7). If those I met in El Romero were struggling with what seemed to them a newly unpredictable and dangerous environment, I was all the more baffled. Despite the generosity and patience I was shown as friends taught me to navigate the physical and social space of the barrio, I often felt confused, unsure, or frightened.

My identity as a young woman and an outsider inevitably shaped my fieldwork in El Romero and my experience of insecurity in particular. Perhaps its most notable effect was that many residents were extraordinarily concerned with my vulnerability in their neighbourhood. Everyone from close informants to complete strangers provided constant warnings about risks and threats, advice about limiting my movements and questions, and offers of protection against perceived dangers. Grateful as I was and am for their efforts, which almost certainly made me safer, this intense and omnipresent concern also meant that, like Hume (2007: 486), I'could never really detach myself from constant feelings of fear and insecurity' due to persistent reminders of my vulnerability.

In these circumstances, the códigos de barrio offered a tantalizing possibility: a structure for and a story about a place that sometimes seemed menacingly unintelligible. Of course I 
wanted to believe in them. I wanted to believe that the people who explained them to mepeople who helped me, protected me, and befriended me-had once and could again live in happier, safer, easier circumstances. But I also wanted to believe for my own sake. These codes promised there had been rules that organized life here on terms that everyone understood, a seductive prospect when I felt engulfed by rumours, secrets, and threats.

In defining the 'affective field site' as one permeated by danger and fear, Skidmore (2009: 311) remarks that it is common for fieldworkers to share their informants' emotions, their feelings of anxiety and vulnerability. Yet the literature on ethnographic methods amid violence tends to 'speak of danger and risk as if these forces are somehow devoid of emotion and objectively manageable' (Hume, 2007: 486). Fieldwork accounts and methodological reflections ponder the security threats (see Sluka, 1990), ethical dilemmas (see KovatsBernat, 2002; Rodgers, 2007) and political questions (see Bourgois, 2001) raised by the violent field in far greater depth than they typically do the emotional complications of the affective field (but cf. Hume, 2007; Wolseth and Jones's contributions to this volume). Attending more fully to the subjective impact of fear on field researchers and the influence of the strategies both conscious and unreflexive - that we adopt to mitigate it promises to enrich our understanding of how violence shapes both the research and writing phases of ethnographic work.

Nostalgia in the affective field is a response not so much to violence itself - that is, to physical insecurity-but to the anxiety occasioned by ontological insecurity. The lack of a 'psychological refuge' from danger (Skidmore, 2009: 305) heightens the urgency of capturing a clear and reassuring narrative, bringing nostalgia to the fore as a 'sort of defensive sensemaking' for both those who inhabit and those who study insecure fields (Brown and Humphreys, 2002: 155). The codes of the barrio were not simply an object of my ethnographic research, but became part of my own experience of doing ethnography amid insecurity. I understood viscerally the longing they encapsulated for an order that could stabilize the uncertainty around me.

The force of this longing outlasted my physical presence in El Romero's affective field and undoubtedly influences how I represent the neighbourhood's past and present. The reassurance I drew from those discourses and the fidelity I felt to the picture of bygone community life my informants recounted have consistently made it a struggle to admit doubt and uncertainty - to confront narrative insecurity - in my writing on El Romero. In unpacking these discourses on barrio codes, it thus becomes necessary to grapple with a double insecurity, a double longing, and a double nostalgia, to bring a critical eye to the needs and desires influencing my own assumptions and narrative practice as well as those of my informants. 


\section{Interpreting nostalgia}

\section{The real and the true}

According to the common account of the códigos de barrio, norms that once shaped neighbourhood life were first discarded by local gangs and, consequently, became impossible for residents in general to enact. A solidary past gave way to an atomistic and anomic present. Not having been present to observe this trajectory and with dissenting interpretations available, I faced the question of the degree to which this narrative could be relied upon to reconstruct El Romero's history and the processes of change that shaped the barrio I encountered.

But asking whether nostalgic discourses accurately reproduce the facts of El Romero's past does not exhaust the issue of whether they convey a true story. Fassin (2014) distinguishes 'reality' and 'truth' as dimensions of narrative veracity. The real is the fact of the matter, 'that which exists or has happened'; the true is the meaning that must be uncovered or 'regained' (2014: 41). Fassin associates each with a particular perspective on human lives: whereas reality is 'horizontal, existing on the surface of the fact,' truth is 'vertical, discovered in the depths of inquiry' (2014: 41).

Returning from Guatemala City, my understanding of the barrio codes fell very much on the 'real' side of Fassin's typology. Confined to the surface of the fact, I initially used these discourses to recount a straightforward movement from past to present. Having depended on this picture of order to steady myself in a difficult field, I relied on the codes as a narrative structure to organize an account of insecurity in El Romero. Uncovering a truer picture of the changing landscape of insecurity involved drawing distance from my own vicarious nostalgia to inquire more deeply into the meaning and function of these accounts: who was (and was not) telling them; when did they tell them; why did they tell them to me; what were they doing for those who told and heard them? Viewed vertically, 'why and for what' are better questions to ask of nostalgia than true or false (Boyer, 2010: 17).

Interrogating informants' statements for dimensions of scripting, performance, and positionality is, of course, part of any process of ethnographic analysis. It may, though, prove particularly challenging for researchers who experience both physical and ontological insecurity in violent fields. The lasting effects of the affective field sustain the appeal of the 'psychological refuge' nostalgia offers. Hence why it was so difficult for me to admit the degree of uncertainty, ambiguity, and narrative insecurity demanded by the complexity of my ethnographic material.

It is not only informants' narratives that must be questioned and challenged in the production of ethnographic accounts. Hume (2007: 492) urges researchers to appreciate the different emotions and reactions generated by competing narratives of violence and to ask why some narratives appear more intelligible than others. Conflicting statements from Eddy and Sara, both lifelong El Romero residents in their early twenties, illustrate the issue. Eddy said that 'two years back, violence started decreasing.' But Sara told me things had been improving somewhat until two years before, when they took a very bad turn. My initial 
inclination, based on other interviews and my own impressions of the neighbourhood's situation, was to agree with Sara and think Eddy mistaken. But the ethnographer's task, following Fassin, is not to adjudicate which account is more real, but to uncover the truth of what Eddy and Sara were each trying to communicate about barrio life.

When people disagreed like this, they were usually prioritizing different kinds of insecurity. Eddy was an MS-13 member during the barrio's gang war. After receiving permission to leave the mara to become a born-again Christian, he gained a wife and child, a middle-school diploma, and a support network through his Pentecostal church. The risk he felt most exposed to-violent death-receded. He felt more physically and psychologically secure. For Sara, what 'changed two years ago is that you can't identify delinquents anymore.' Gang members abandoned their distinctive stylistic markers and delegated many tasks to collaborators to minimize police interference. Things worsened for Sara because she could not identify sources of danger and react appropriately. Violence seemed more present and less controllable. She felt 'unsafe as a woman, unsafe as a human being, unsafe as mother.'

The particular force and content of nostalgic discourses varied according to people's personal experience of insecurity past and present, gangs then and now, violence before and after. As Sara's invocation of womanhood and motherhood implied, gender contributes to shaping that experience, and thus also the nostalgia to which it may give rise. Generating different patterns of risks and possibilities for agency with regards to violence, gender also influenced people's assessments of the nature and profile of insecurity in local life, as well as how they understood and described change over time.

It also played a part in my own reception of their accounts. As a young woman working alone in an unfamiliar and violent environment, the risks Sara ran and the stories she told were much closer to my own experience of El Romero than Eddy's. Her anxiety and nostalgia made more intuitive sense to me than his confidence and optimism. Eddy's account was of course no less 'real' than Sara's. The truth of his story was merely less immediately accessible to me because of the gulf between our embodied experiences of the neighbourhood and the kinds of physical and psychological insecurities involved.

\section{Barrio codes, local history, and the morality of violence}

It is essential not to impose a complete disjuncture between the real and the true. Whether or not nostalgic discourses of barrio codes are 'real' in the sense of faithfully reproducing the facts of local processes of change matters for how we understand gang development, patterns of violence, and the social history of Guatemala City's marginal neighbourhoods. They could be wholesale inventions and still valuable for understanding how insecurity is perceived. However, the difference matters: memories and fantasies are importantly distinct. But how could I assess the extent to which the codes of the barrio corresponded to one or the other of these categories? 
On the level of fact or the 'real', there is evidence to support the narrative I have outlined. I heard the same general account of the development of maras and extortion in other gang-affected areas around the capital. In one MS-13 territory, residents reported norms similar to those attributed to El Romero's earlier cliques to a team of Guatemalan researchers investigating the neighbourhood's history. Rules against internal predation were said to be strictly enforced by gang members who served as the local 'authority - and not only the authority by force, but the moral authority as well' (Lemus Barahona, 2014, personal communication). The clique was seen, however, to have abandoned this role upon introducing systematic local extortion from 2007. There appears to have been both a common sense among gangs that one's barrio was not an acceptable target and a general disruption of this norm coinciding with the rise of gang-run extortion economies.

Researchers who have been able to observe gang change more directly in the course of longitudinal fieldwork present corroborating accounts. In the late-1980s, Guatemala City's gang members positioned their organizations within 'the class world of the deserving poor,' expressing opinions like "robbing from the poor is evil" and "robbing from an equal would not be right" (Levenson, 2013: 67). Yet over the last 25 years, Levenson argues, these gangs have gone 'from protecting neighbors to abusing them' (2013: 8).

The same pattern recurs elsewhere in Central America, as illustrated by Rodgers' longrunning research on one Managua barrio's gangs. These Nicaraguan pandillas once complied with a 'golden "rule" ...not to prey on local neighbourhood inhabitants' (2006: 275). Here too, the prioritization of profit-making activities transformed the prevailing relationship between gang and barrio. Involvement in the drug economy from the late 1990s converted the pandilla from 'an organization that displayed a sense of social solidarity with the local community to a more exclusive and predatory group' (2015: 31).

Criminal economies have affected other urban communities in ways that recall my informants' complaints about a declining ethos of reciprocity. In San Salvador, people linked the disintegration of local collective life and support networks to the formation of mara cliques in their neighbourhoods (Hume, 2007: 491). The gang's involvement in drug trafficking in Rodgers's Managua research site not only affected members' behaviour, but also 'transformed the moral landscape within the community' (2015:36).

It is highly plausible that, as El Romero's gangs became more focused on criminal economies, they became more violent in and predatory on their neighbourhood and, further, that this had far-reaching consequences for local life. However, it is virtually impossible to confirm to what extent the barrio's 'codes' as currently represented correspond to norms that did, in fact, order social life in the past. Enough people insisted that the barrio and its gangs had always been dangerous to call into question the degree to which the 'old codes' ever really regulated local behaviour or relationships.

Conflicting accounts may complicate the reality of stories of barrio codes without necessarily undermining - in Fassin's sense - their truth. That the codes of the barrio were never perfectly executed does not mean they never existed. Social rules always co-exist with a certain number who transgress and reject them (Hart, 1994: 56). Thus, when Cadejo said 
that you might always be robbed in the barrio, he could be correctly recalling particular occurrences; Wuicho's insistence that 'before, they didn't rob you in the Colonia' could refer with equal accuracy to a general norm. We can distinguish two kinds of claims about the neighbourhood's past: one about certain facts of what occurred, and another about the kind of moral world residents and gang members have inhabited. When people said the codes had been discarded, they were not claiming to witness completely novel behaviour. They were saying that a consensus around a model of community and relationships within it no longer holds as it once did.

The ultimately irresolvable question of the precise measure of reality in any account of the barrio codes should not obscure the truths that emerge from these narratives regarding changing perceptions of local gangs and experiences of violent insecurity. They speak to a shifting ethic of violence and a splintering local social imaginary. Like Hobsbawm's social bandits who, despite being outside the law, 'remain within peasant society' and refrain from victimizing members of this in-group (2001: 20), mara cliques seem once to have remained within the neighbourhood's broader social and ethical world. Gang members always behaved in ways that displeased others and violated some of their values. They disrupted expectations of how boys and young men should manage the transition to adulthood, work, and family life. Yet despite holding conflicting values to many of their neighbours with regards to decency, respectability, and responsibility, mara participants shared with them certain notions of neighbourhood solidarity and reciprocity and an understanding of the barrio as a morally-relevant unit.

In return, being a gang member did not necessarily radically alter one's position in local social worlds. It was 'a finite social role' (Rodgers, 2006: 284), neither a permanent nor exclusive identity. In the 1990s, gang members also belonged to church groups, sports teams, and arts projects. By their early twenties, virtually all 'aged out' of active gang membership (back) into broader local social networks. Gang involvement reflected poorly on a young person, but it did not exhaust who they were or define who they might become.

This changed as the extortion economy became increasingly central for the mara, transforming its morality of violence. Street gangs that saw themselves and were seen as part of local normative communities became parasitic on and predatory within their neighbourhoods. It is beyond this paper's scope to enter fully into how and why this happened, but the prison system has been especially important (see Levenson, 2013). Although virtually the entire leadership of the M-18 and MS-13 are imprisoned in maximum-security institutions, incarceration has not diminished gang capacity. If anything, it enhanced their organization and professionalization. Especially after the move to segregated prisons for members of each mara in 2005, the penal system brought cliques from around the region into closer contact, expanding their territorial reach, resource bases, and operational integration.

But perhaps the most significant outcome of shifting the mara's centre of gravity into the prison system was on the level of group culture. Gangs came unmoored from the physical and social space of their barrios. In the late 1980s and early 1990s, gang members identified 
with their neighbourhoods: their "'us" included the poor' (Levenson, 2013: 3). But incarceration in segregated gang prisons shrank the social world of members down to their mara, reinforcing their ties to each other and weakening any other claims on them (Cruz, 2014). Unlike the finite social role gang membership once represented, in Guatemala's prisons, 'mareros are only that' (Levenson, 2013: 113). The neighbourhood no longer binds local gangs; their worlds of reciprocity and responsibility no longer include their barrios.

This simplified transition from moral community to ethical and social estrangement between gangs and their neighbourhoods presents rather too neat a picture at both ends of the trajectory. For residents of the communities they come from and operate in, gang members often appear as 'dangerous intimates' (Penglase, 2014): figures characterized by both familiarity and otherness, by confusion and contradiction. This is and always has been the case in El Romero. Even so, residents' nostalgic narratives strongly suggest that something important has changed in the balance of this relationship, in the constellation of intimacy and danger.

\section{Using nostalgia}

Nostalgia as justification and critique

Nostalgia for El Romero's 'old codes' described many residents' perceptions of distressing changes to the moral landscape of violence over the previous 20 years. But these accounts of the past were about much more than the past. Nostalgia here is not just about relating change, but coping with it by marshalling reassuring and identity-affirming narratives (Brown and Humphreys, 2002).

Nobody claimed that the barrio codes were reliable predictors of neighbourhood events or interactions in the present. They portray 'the way the world ought to be, whether or not anyone actually behaves that way' (Pirie, 2013: 130). People in El Romero used the códigos de barrio to advance a vision of social and moral order, to explain why what they were experiencing was wrong, and to reassert their convictions about the contours of decency and respectability. They gave them a way to reconnect with the 'moral resources' that sustain ontological security (Giddens, 1991: 9).

Defined by an unflattering contrast of present to past, nostalgia is always at least implicitly about what is good, laudable, reprehensible, or regrettable in the life of an individual or group. It is a mode of social and moral critique. The form nostalgic narratives took in El Romero-variations on the theme of barrio codes-further reinforced this capacity. The 'normative vocabulary' of codes and rules provides 'resources for justification, condemnation and argument' (Cover, 1983: 46; Hart, 1994: 85). It is a language of standards and of accountability.

Discourses of barrio codes present a past in which street gangs and their violence were constrained by certain boundaries between the tolerable and intolerable, legitimate and illegitimate. The fundamental critique is that Guatemala City's gang members are no longer accountable to their barrios. Around this fulcrum, however, people used nostalgic accounts 
of barrio codes to do a range of normative work, making diverse claims about the past and mobilizing nostalgia for various projects in the present. The códigos de barrio have a different moral valence and validity depending on one's position in the neighbourhood and with respect to its gangs. Ex-pandilleros, for instance, typically used the codes to tell me about a time when the gang itself was good - for its members and for the neighbourhood. Other residents, in contrast, never accepted the mara's own code as a moral standard, although they retrospectively saw it as useful in keeping violence more limited and predictable. Older men and women I spoke with used barrio codes to depict a time when the neighbourhood was a good place-apart from or in spite of the gang. In both instances, my interlocutors asserted a kind of goodness, claimed a sort of moral worthiness, but to different ends.

For ex-members, this was an exculpatory discourse, distinguishing the excessive, illegitimate violence gangs practice today from the more acceptable or less blameworthy violence in which they took part. It served as a claim about why they were and are good people despite their gangs becoming bad. These performances of decency were strongly gendered, recollecting Presser's (2009) description of interviewing violent offenders as a female researcher. Ex-pandilleros often insisted that sexual violence was not tolerated during their membership in the 1980s or 1990s. Those who more recently belonged to the M18 , on the other hand, spoke of sexual violence as systematic and even enforced (for instance, participation in gang rape was part of several informants' initiation). But in every such exchange, they did so in the third person, shifting from ' $\mathrm{I}$ ' and 'we' to 'they', distancing themselves from these disclosures even as they expressed shame and remorse for acts they had clearly personally committed. Expressing longing for their gang's 'old codes' and condemnation or regret for their violation gave formerly violent men a way of " doing" goodness with me' through our conversations (Presser, 2009: 267).

The nostalgic morality of residents more generally was less about personal exoneration than social imaginary and social critique. The accounts of barrio codes that they shared with me were protests against what they perceived as the mara's changing morality of violence and its consequences for local safety and social order. They conveyed what people felt they had lost and had taken from them: their neighbourhood's viability as a normative unit, limits on and a measure of predictability to the danger gangs represented.

Nostalgia's critical capacities are not confined to justifying the past or assessing the present. Conjuring social visions that differ from prevailing arrangements, nostalgic discourses can also look ahead. It served this function for Rafa and Cadejo, two close friends and community activists who were involved with El Romero's early Barrio-18 cliques. Their personal histories provided two kinds of resources for their arts and educations projects in the neighbourhood. The first was practical: having disengaged from the M-18 when aging out was still typical, they retained a degree of status with the local clique that permitted them some limited latitude to engage young people on topics which the mara typically opposed, such as violence prevention.

The second resource was a set of scripts about barrio codes that they used to communicate a nostalgic vision of how things should-and could-go otherwise. In doing 
so, they deployed the 'past as a set of resources for the future' (Pickering and Keightley, 2006: 937). Plays they presented to El Romero's young people displayed mutual aid between friends as both a virtue and a practical way to cope with danger. They tried, Rafa explained, to transmit the 'old codes' they had known in their youth in the hope that if people 'remember what we were' it would influence their conception of 'what we could be.'

Nostalgia thus potentially 'carries with it a politics of the future' (Boyer, 2010: 25), as demonstrated by the young activist Mono and his friends. They were the most socially and politically engaged of El Romero's adolescents, arranging activities for children, liaising with local government authorities, and organizing community events. They habitually used the códigos de barrio to explain the changing nature of insecurity and sociality in their neighbourhood, offering accounts laced with nostalgia for a past they were too young to have experienced. But the vision they conjured was ultimately more future-oriented than backwards-looking. Affiliating themselves with the old codes, they expressed not a personal experience of the past, but fidelity to a future alternative. As they faced the multiple insecurities of being young men in mara territory, drawing from the past provided these boys with a way 'to sustain a commitment to actualize the possibilities they know to exist,' but which present circumstances prevent them from bringing about (Hirsch and Stewart, 2005: 271). For populations subject to violence and domination, to conflict and displacement, to the loss of control over one's safety and social world that occasions ontological insecurity, nostalgia can be a source of critique, commitment, and aspiration, a resource for persistence and some measure of resistance.

\section{Ethnography and nostalgia}

Nostalgia's normative work does not end at the edges of our field sites. The critical and moral force of that language operates as much in the conversation between ethnographer and audience as between informant and researcher. Ethnography has always been infused with what Berliner calls a 'disciplinary exo-nostalgia', a longing for the pasts of other peoples and places (2014: 19). For early anthropologists, this took the form of primitivist nostalgia for cultures perceived to be collapsing and vanishing (Berliner, 2014: 24). More recently, the preferred object of exo-nostalgia shifted to 'the powerless facing social instability, urban poverty, economic migration, war and political disempowerment' (2014: 29).

Like ethnographies of the 'powerless Other' generally, ethnographies of violence are frequently written in a tone of 'indignation in front of loss and crisis' (Berliner, 2014: 30). Reviewing the post-Cold War anthropology of Central America, Burrell and Moodie find a 'rueful' and 'disillusioned mode' characterizing many texts (2015: 385). Recent studies of the region's street gangs built on decades of longitudinal research can be counted among these. Levenson (2013: 49) describes Guatemala City as an 'urban crucible stripped of its political and ethical past.' The mutation of Nicaragua's pandillas seems to Rodgers (2015: 37) 'all the more tragic in view of the country's inspirational utopian past.' 
The 'postwar disillusion' of Central Americans has provided an object of study for ethnographic research (Burrell and Moodie, 2015: 389). But it is also an emotional and discursive structure in which ethnographers themselves participate and from which they draw to condemn the ways in which neoliberal states have been failing to secure the lives and livelihoods of their citizens. For ethnographers, too, nostalgia operates as a mode of social critique in the past tense. It names the wrongs and injustices of the present with reference to other possibilities that promise better, more moral, more human arrangements of collective life. What distinguishes nostalgia is that this realm of possibility is placed behind us in history rather than on the horizon of the future.

I have already described the pull of nostalgia for me while experiencing physical and psychological insecurity in El Romero. But the appeal of 'nostalgic forms of thinking and writing' for anthropologists persists beyond the field (Berliner, 2014: 19), and it may be particularly forceful when insecurity, exploitation, and suffering are central aspects of the social worlds we study. They provide a resource in the face of certain political and ethical dilemmas characteristic of ethnographies of violence.

As Bourgois observes, 'ethnographers never want to make the people they study look ugly,' which gives rise to strong impulses towards positive representations of the vulnerable (2003: 15; also Penglase, 2014: 33). Anxious to shield people we often like-and to whom we have acquired responsibilities - from judgement and condemnation, to avoid fueling hateful rhetoric or harmful policies, we may smooth over the moral compromises people make, the indignities they suffer and inflict, the truly ugly things that people do to themselves and each other in hideous circumstances. In Bourgois's case (2001), he came to feel that Cold War-era political imperatives had led him to 'sanitize' his representation of violence among Salvadoran peasants in the 1980s. The 'ethnographic refusal' to put on display uncomfortable and messy features of places and people we study drives the accusations of romanticizing that have long dogged ethnographies of the dispossessed (Ortner, 1995).

Prioritizing 'positive accounts of the past to the exclusion of less than romantic aspects of experience' (Pickering and Keightley, 2006: 923), nostalgia enables us to admit more of the ugliness of the present into our accounts while still emphasizing the moral worthiness, political righteousness, or blamelessness of our research subjects. Even as I moved away from seeing El Romero's nostalgic discourses as reconstructions of local history, I still leaned on the barrio codes as a story that let me tell the goodness of this place and its people. This narrative absolves people of culpability and complicity: insecurity is something that has happened to them, their capacity to live up to laudable standards of solidarity and reciprocity is something that has been taken from them.

Describing a time when those codes worked conjures a picture of an autonomous, integrated, harmonious community. But it also covers over the complexity and internal conflicts that are an essential part of the life of any social group, perhaps especially those living with precarity and marginality. We should not aim to vindicate nostalgia as history, but to unpack the critiques of change and crisis it conveys while respecting the ambivalent complexity' of social worlds both past and present (Ortner, 1995: 178). Overly-romantic 
histories are not the only risk of failing to do so. Taking on nostalgia as reality instead of inquiring into its truth also distorts the present, portraying El Romero as too simply good before and too simply bad today. It also misapprehends the true verb tense of these narratives. Discourses of barrio codes referred to the past, but they were told in and for the present.

\section{Conclusion}

Ontological insecurity arises when our practical and moral maps prove insufficient to orient and guide us. When danger seems unpredictable and ubiquitous, this condition encompasses ethnographic researchers as much as their subjects. For both, ontological insecurity provokes nostalgia, offering ways of coping with and accounting for violence and volatility.

In postwar Central America, a sense of degeneration into insecurity 'resonates in everyday life throughout the region, but perhaps especially its urban cores' (Burrell and Moodie, 2015: 392). It certainly resonated strongly in Guatemala City's red zones. Like Sara, many in El Romero found it 'no longer possible to live peacefully here.' They feared the gang, distrusted each other, and felt they lacked control over what happened around them and to them. Looking to the past, they told of a time when things were otherwise: when gangs protected the barrio instead preying on it, when El Romero was not just a neighbourhood but a community. In so doing, they advanced-implicitly or explicitly - a form of social critique. Through eulogizing the 'old codes', people asserted a vision of what their social world should look like and how relationships within it should proceed.

Nostalgia performed similar roles for me in conducting ethnographic research on El Romero. The codes of the barrio provided tools for steadying myself in the field, structuring my narrative of gang violence, and constructing a critique of the circumstances faced by barrio residents. Nostalgic need and desire manifest throughout the ethnographic endeavour. But understanding the relationship between nostalgia and ethnography requires more than simply dividing ethnographers 'into those who fall for nostalgia and those who do not' (Berliner, 2014: 27).

I propose, following Fassin (2014), that there are two importantly distinct sorts of questions we can put to nostalgic narratives. There is the horizontal, factual inquiry: to what extent are they real? But there is also the vertical excavation: in what way are they true? That I cannot, with any precision, ascertain their historical veracity undeniably complicates their use in ethnographic analysis. Nevertheless, I argue that they tell us something true about the lived experience of insecurity in El Romero. Through the story of the decline of the códigos de barrio, people related the mara's changing ethic of violence and its consequences for local social imaginaries and spheres of reciprocity. Although it is not an exhaustive or uncontested account of this neighbourhood's past or processes of change, this narrative conveys the distress occasioned by instability in the shape and scope of people's normative worlds. 
This distress must not be seen as the whole truth of the place. Focusing exclusively on decline and disorder reproduces popular stereotypes of the red zones as spaces of complete social and moral breakdown. El Romero is no more a morally bankrupt place now than it was a perfectly solidary one in the past. Although catastrophe pervades the narratives they use to describe their situation, people here keep going, finding ways to get by and pursue their projects for themselves. Many continue to enact values of reciprocity and mutual aid, sacrificing time and resources to one another, taking on burdens and risks for each other. Yet everyone insists that no one can be trusted, that everyone is potentially dangerous. They struggle daily to reconcile profound insecurity with their conceptions of what it takes to be a good person and a decent community.

Misapprehending what nostalgia means for ethnographic subjects, research, and writing may do a grave disservice to the complexity and tenacity of that struggle. Romanticizing the past of our field sites risks evacuating agency from the present and a sense of possibility from the future. Emphasizing the functional and normative work of nostalgia amid insecurity restores that complexity, giving us greater insight into how people understand and experience what violence does to their social worlds.

\section{Acknowledgments}

I am grateful to Gareth Jones, Dennis Rodgers, and the anonymous reviewers for their constructive feedback on previous versions of this article.

\section{Declaration of Conflicting Interests}

The author declares no potential conflict of interest with respect to the research, authorship, or publication of this article.

\section{Funding}

The research and fieldwork informing this article received support from the Social Sciences and Humanities Research Council of Canada and the Harry Frank Guggenheim Foundation.

\section{Notes}

1. 'Zona roja' designates (typically poor urban) districts infamous for high rates of violence, gang activity, or other forms of criminality. The term dates from Guatemala's internal conflict, when military maps coloured areas of guerrilla control red.

2. El Romero and all names are pseudonyms. Fieldwork took place over 16 months between 2011 and 2013. Where not otherwise cited, all quotations are taken from my interviews and conversations with residents during this period.

3. Informants generally used pandilla and mara interchangeably, as they did 'pandillero' and 'marero'.

4. Associates' estimates of clique membership varied between 80 and 300 .

Discrepancies are largely due to whether or not the figure included incarcerated 
pandilleros and how many 'ranks' were counted (not all degrees of gang association impart full membership).

5. The codes that organize gang behaviour have been a persistent theme in gang studies since Thrasher's (1927) foundational work. Urban ethnographers have also examined the question of how such codes relate to the broader social order and community mores of gangs' neighbourhoods (see especially Anderson, 1999).

6. Violence in Guatemala increased sharply from the mid-1990s to 2009, when the official homicide rate peaked at 46.5/100,000. Police figures show fewer murders each year from 2009 to 2015, but the national forensics institute recorded rising homicide numbers each of those years (UNODC, 2013; El Periódico, 2016; INACIF, 2016).

\section{References}

Anderson E (1999) Code of the Street. New York: W.W. Norton.

Berliner D (2014) Are anthropologists nostalgist? In: Angé O and Berliner D (eds.)

Anthropology and Nostalgia. New York: Berghahn Books, pp. 17-34.

Bourgois P (2001) The power of violence in war and peace: Post-Cold War lessons from El

Salvador. Ethnography 2(1): 5-34.

Bourgois P (2003) In Search of Respect (2 ${ }^{\text {nd }}$ edition). Cambridge: Cambridge University Press. Boyer, D (2010) From algos to autonomos: Nostalgic Eastern Europe as postimperial mania.

In: Todorova M and Gille Z (eds.) Post-Communist Nostalgia. Oxford: Berghahn Books, pp. 17-28.

Brown AD and Humphreys M (2002) Nostalgia and the narrativization of identity: A

Turkish case study. British Journal of Management 13: 141-159.

Burrell JL and Moodie E (2015) The post-Cold War anthropology of Central America. Annual Review of Anthropology 44: 381-400.

Cover RM (1983) Nomos and narrative. Harvard Law Review 97(4): 4-68.

Dames N (2010) Nostalgia and its disciplines. Memory Studies 3(3): 269-275.

El Periódico (2016) Guatemala es la quinta nación más violenta de América Latina, 25

January.

Fassin D (2014) True life, real lives: Revisiting the boundaries between ethnography and fiction. American Ethnologist 41(1): 40-55.

Giddens A (1991) Modernity and Self-Identity. Stanford: Stanford University Press.

Greenhouse CJ (2002) Altered lives, altered states. In: Greenhouse CJ, Mertz E and

Warren KB (eds.) Ethnography in Unstable Places. Durham: Duke University Press, pp. 134.

Hart HLA (1994) The Concept of Law, $2^{\text {nd }}$ edition. Oxford: Clarendon Press.

Hirsch E and Stewart E (2005) Ethnographies of historicity. History and Anthropology 16(3):

261-274.

Hobsbawm E (2001). Bandits. London: Abacus.

Hume M (2007) '(Young) men with big guns': Reflexive encounters with violence and youth in El Salvador. Bulletin of Latin American Research 26(4): 480-496. 
INACIF (2016) Necropsias realizadas a nivel nacional, 2009-2015. Available at:

http://www.inacif.gob.gt/index.php?option=com content\&view=article\&id=97\&Itemid=1 $\underline{8}$.

Kovats-Bernat JC (2002) Negotiating dangerous fields: Pragmatic strategies for fieldwork amid violence and terror. American Anthropologist 104(1): 208-222.

Little WE (2009) Living and selling in the 'new violence' of Guatemala. In: Little WE and Scott TJ (eds.) Mayas in Postwar Guatemala. Tuscaloosa: University of Alabama Press, pp. 54-66.

Levenson DT (2013) Adios Niño. Durham: Duke University Press.

McAllister C and Nelson DM (2013) Aftermath: Harvests of violence and histories of the future. In: McAllister C and Nelson DM (eds.) War by Other Means. Durham, NC: Duke University Press.

Mendoza CA and Méndez C (2013) 7 mitos sobre la violencia homicida en Guatemala. El Periódico, 23 January.

Moodie E (2009) Seventeen years, seventeen murders: Biospectacularity and the production of post-Cold War knowledge in El Salvador. Social Text 27(2): 77-103.

Ortner SB (1995) Resistance and the problem of ethnographic refusal. Comparative Studies in Society and History 37(1): 173-93.

Penglase RB (2014) Living with Insecurity in a Brazilian Favela. New Brunswick, NJ: Rutgers University Press.

Pickering M and Keightley E (2006) The modalities of nostalgia. Current Sociology 54(6): 919941.

Pirie F (2013) The Anthropology of Law. Oxford: Oxford University Press.

Presser L (2009) Power, safety, and ethics in cross-gendered research with violent men. In: Huggins MK and Glebbeek M (eds.) Women Fielding Danger. Lanham, MD: Rowman and Littlefied, pp. 251-270.

Rodgers D (2006) Living in the shadow of death: Violence and social order in urban Nicaragua, 1996-2002. Journal of Latin American Studies 38(2): 267-92.

Rodgers D (2007) Joining the gang and becoming a broder: The violence of ethnography in contemporary Nicaragua. Bulletin of Latin American Research 26(4): 444-461.

Rodgers D (2015) The moral economy of murder. In: Auyero J, Bourgois P, and ScheperHughes N (eds.) Violence at the Urban Margins. Oxford: Oxford University Press, pp. 2140.

Skidmore M (2009) Secrecy and trust in the affective field: Conducting fieldwork in Burma. In: Huggins MK and Glebeek L (eds.) Women Fielding Danger. Lanham, MD: Rowman and Littlefield, pp. 301-323.

Sluka JA (1990) Participant observation in violent social contexts. Human Organization 49(2): 114-126.

Taylor C (2002) Modern social imaginaries. Public Culture 14(1): 91-124.

Thrasher FM (1927) The Gang. Chicago: University of Chicago Press.

UNODC (2013) Intentional homicide count and rate by country/territory (2000-2012). In: 
Global Study on Homicide. Vienna: UNODC.

\section{Author biography}

Katherine Saunders-Hastings is Lecturer in Latin American Studies at the Institute of the

Americas, University College London where she teaches urban and political anthropology. She researches urban violence and criminal economies in Latin America, with a particular focus on the impact and experience of insecurity in gang-affected neighbourhoods of Guatemala City. 